\title{
Genetic detection of peste des petits ruminants virus under field conditions: a step forward towards disease eradication
}

Waqas Ashraf ${ }^{1,2^{*}}$, Hermann Unger ${ }^{3}$, Sunaina Haris ${ }^{1,2}$, Ameena Mobeen ${ }^{1,2}$, Muhammad Farooq ${ }^{1,2}$, Muhammad Asif ${ }^{1,2}$ and Qaiser Mahmood Khan ${ }^{1,2^{*}}$

\begin{abstract}
Background: The devastating viral disease of small ruminants namely Peste des petits ruminants (PPR) declared as target for "Global Eradication" in 2015 by the Food and Agriculture Organization (FAO) and the World Organization for Animal Health (OIE). For a successful eradication campaign, molecular diagnostic tools are preferred for their specificity, efficacy and robustness to compliment prophylactic measures and surveillance methods. However, molecular tools have a few limitations including, costly equipment, multi-step template preparation protocols, target amplification and analysis that restrict their use to the sophisticated laboratory settings. As reverse transcription-loop mediated isothermal amplification assay (RT-LAMP) has such an intrinsic potential for point of care diagnosis, this study focused on the genetic detection of causative PPR virus (PPRV) in field conditions. It involves the use of a sample buffer that can precipitate out virus envelope and capsid proteins through ammonium sulphate precipitation and exposes viral RNA, present in the clinical sample, to the LAMP reaction mixture.
\end{abstract}

Results: The test was evaluated using 11 PPRV cultures, and a total of 46 nasal swabs ( $n=32$ collected in the field outbreaks, $n=14$ collected from experimentally inoculated animals). The RT-LAMP was compared with the reverse transcription-PCR (RT-PCR) and real-time quantitative RT-PCR (RT-qPCR) for its relative specificity, sensitivity and robustness. RT-LAMP detected PPRV in all PPRV cultures in or less than 30 min. Its detection limit was of 0. $0001 \mathrm{TCID}_{50}$ (tissue culture infective dose-50) per $\mathrm{ml}$ with 10-fold higher sensitivity than that of RT-PCR. In 59.4\% of the field samples, RT-LAMP detected PPRV within 35-55 min. The analytical sensitivity and specificity of the RTLAMP were equivalent to that of the RT-qPCR. The time of detection of PPRV decreased by at least forty minutes or 3-4 $\mathrm{h}$ in case of in the RT-LAMP as compared with the RT-GPCR and the RT-PCR, respectively.

Conclusions: The sensitive and specific RT-LAMP test developed in this study targeting a small fragment of the $\mathrm{N}$ gene of PPRV is a rapid, reliable and applicable molecular diagnostic test of choice under the field conditions. RT-LAMP requiring minimal training offers a very useful tool for PPR diagnosis especially during the "Global PPR Eradication Campaign".

Keywords: Peste des petits ruminants virus (PPRV), Reverse-transcription loop mediated isothermal amplification (RT-LAMP), Nucleocapsid gene (N), Robust diagnosis

\footnotetext{
* Correspondence: waqasasahrafnibge@gmail.com; qk_5@yahoo.com

${ }^{1}$ National Institute for Biotechnology and Genetic Engineering (NIBGE),

Faisalabad, Pakistan

Full list of author information is available at the end of the article
} 


\section{Background}

Peste des petits ruminants (PPR) is an acute, highly contagious viral disease of small ruminants that is considered one of the major constraints for efficient small ruminant production in the developing countries. It is a notifiable, List-A disease to the OIE caused by peste des petits ruminants virus (PPRV) [1]. Since its emergence in West Africa in the 1940s, PPR has spread across vast regions of the Africa, Middle East, Arabian Peninsula, and Southern Asia [2]. PPR is endemic in Pakistan where approximately half $(48.3-48.5 \%)$ of its small ruminant population is seropositive $[3,4]$. The disease mainly exists in three pathogenic, per-acute, acute and sub-acute, forms. However, acute form is the most common form that causes $80-90 \%$ mortality in individual flocks [5]. Once the host is infected with PPRV, general viraemia develops within 4-6 days followed by high fever (104-106 $\left.{ }^{\circ} \mathrm{F}\right)$, marked salivation, shallow erosions in the oral mucosa, serous to purulent oculonasal discharge, dyspnea, coughing, pneumonia and diarrhea [6, 7]. In the later stages, a sub-normal temperature of $101-102{ }^{\circ} \mathrm{F}$ and dehydration due to diarrhea can lead to hypovolumic shock and death of the affected animals [8].

PPRV; the causative agent of the disease, is a member of the genus Morbillivirus, in the family "Paramyxoviridea". It is a negative-sense, single-stranded RNA virus. The genome of PPRV, viz. 3'-N-P-M-F-H-L-5' encodes six structural proteins namely nucleocapsid, phosphoprotein, matrix, fusion, haemagglutinin and large polymerase [9-11]. Among these, nucleocapsid (N) protein gene is the most abundantly transcribed gene in the host cells and is therefore preferred target site for genomic detection of PPRV [12]. Conventionally, diagnosis of PPRV relied on serological techniques and virus isolation from clinical samples through its propagation in adaptable cell lines [13-15]. However, these techniques are labor-intensive and insensitive for PPRV detection especially during latent phase of the infection [16, 17]. In contrast, reverse transcription polymerase chain reaction (RT-PCR) is considered as standard diagnostic test for PPR worldwide $[14,18]$. However, limitations associated with RT-PCR including its high cost and pre-requisite for scientific manpower render it unsuitable for low or middle-income country settings [19]. Accordingly, the World Health Organization (WHO) recommends that an ideal diagnostic test for such countries should meet the ASSURED (Affordable, sensitive, specific, user-friendly, robust, equipment free, deliverable to the end user) guidelines [20, 21]. The invention of isothermal technologies, like loop mediated isothermal amplification (LAMP) assay, for DNA amplification is a step-forward towards the development of ASSURED diagnostic tests [21]. LAMP based amplification of target nucleic acid is based on isothermal amplification of template DNA utilizing the strand displacement activity of Bst or Bsm DNA polymerase enzyme originated from Bacillus stearothermophilus or Bacillus smithii, respectively [22]. The stem-loop structures generated, at an initial phase, during LAMP initiate exponential amplification process that results in rapid accumulation of DNA amplicons of varying lengths $[22,23]$. The LAMP products can simply be visualized with naked eye after the addition of fluorescent DNA-intercalating dyes such as SYBR Green I, propidium iodide and calcein to the reaction mixture. In addition, the generation of LAMP products can also be monitored on a real-time basis by measuring the change in fluorescence over a specified interval with an ESE-Quant tube scanner [23]. Here, we report the development of a one-step, single tube, $\mathrm{N}$ gene based RT-LAMP assay for direct detection of PPRV in clinical samples (swab extracts), cell culture supernatants, obviating the need for RNA extraction and cDNA synthesis step that can potentially make it a suitable diagnostic test for on-site detection of PPRV particularly during eradication campaign in low income country settings.

\section{Results}

Optimization of RT-LAMP Assay for the detection of PPRV in culture supernatants

The success of an RT-LAMP assay mainly depends on three factors including primer concentration, optimal reaction temperature and template amount. Optimal primer concentration was found to be $0.25 \mu \mathrm{M}$ for each of the outer primers (F3 and B3) and $1.25 \mu \mathrm{M}$ for each of the inner primers (FIP and BIP) to achieve threshold increase of $>30 \mathrm{mV}$ for three consecutive readings. Once the primer concentration was reduced to half of the above-mentioned values, it compromised the efficiency of the reaction thus resulting in the drop in signal below the threshold value (Fig. 1). The optimal reaction temperature for each primer pair was determined using a gradient PCR (IQ5 ${ }^{\mathrm{TM}}$, BioRad, USA) prior to its use in RT-LAMP assay. Accordingly, the assay was carried out at an increasing gradient of temperature that ranged from $50{ }^{\circ} \mathrm{C}$ to $62{ }^{\circ} \mathrm{C}$. Gel electrophoresis of reaction products revealed amplification at three different temperatures including $53{ }^{\circ} \mathrm{C}, 55{ }^{\circ} \mathrm{C}$ and $58{ }^{\circ} \mathrm{C}$. Among these, best amplification curve with high specificity was achieved at $58{ }^{\circ} \mathrm{C}$ (Fig. 2). Optimal template concentration for RT-LAMP assay was determined using a standard curve method. For this, tenfold serial dilutions of PPRV cell culture supernatant were prepared and subsequently subjected to RT-LAMP assay along with positive and no template controls (NTCs). The amplification curves for the positive control and the dilution factors viz; $10^{-1}$ to $10^{-4}$ showed typical four phases of amplification including the baseline, exponential phase, linear phase and a plateau within $60 \mathrm{~min}$ from the start of the assay. Amplification curve for $5^{\text {th }}$ dilution crossed 

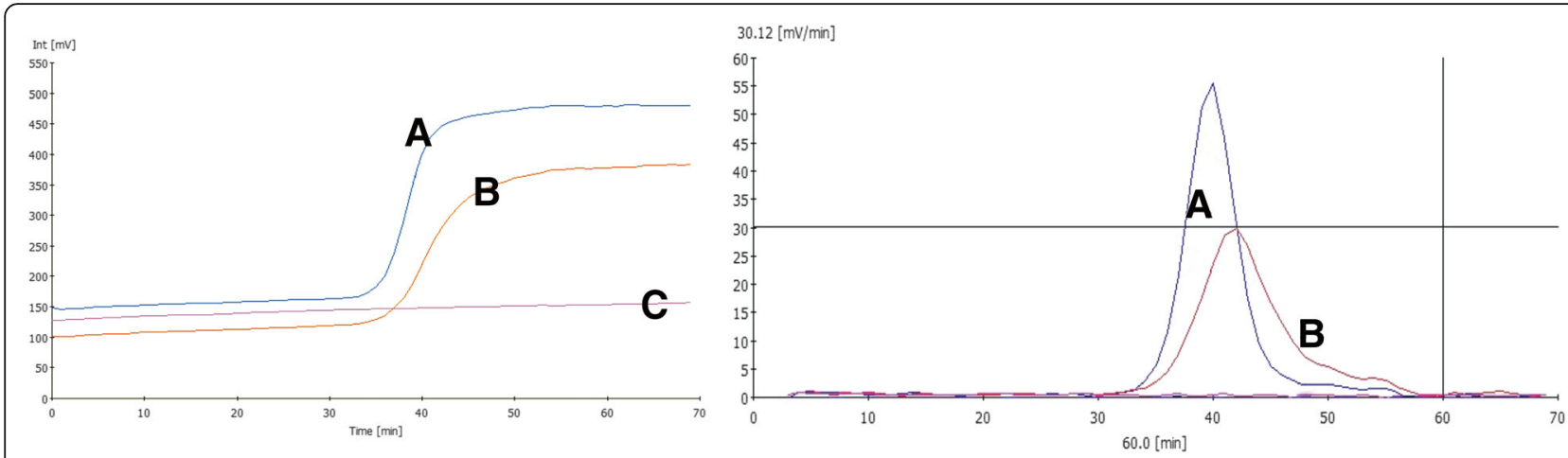

Fig. 1 Optimization of primer concentration for $\mathrm{N}$-gene based RT-LAMP assay. Curve A indicate amplification at optimized primers concentration while B indicate amplification efficiency at half of that primer concentration at which the increase in amplification signal per minute did not exceed threshold value of $30 \mathrm{mVolt} / \mathrm{min}$. Negative control is indicated by a magenta colored line labeled as C

threshold limit (30 $\mathrm{mV} / \mathrm{min}$ ) after $65 \mathrm{~min} \mathrm{(Fig.} \mathrm{3,}$ Additional files 1 and 2) while NTC did not show any amplification. A standard curve was plotted with the log template concentration as the $\mathrm{x}$ value and the time of positivity (detection time, $\mathrm{Td}$ ) as the $\mathrm{y}$ value. The $\mathrm{y}$ intercept value (line representing the best fit) calculated using the least square method of linear regression was found to be $69.32 \mathrm{~min}$. Accordingly, a maximum time limit of $60 \mathrm{~min}$ was set for the test to decide for positivity of the tested sample to ensure specific detection and rule out false positives. The detection limit of the assay $\left(10^{-4}\right.$ $\mathrm{TCID}_{50} / \mathrm{ml}$ ) was 10 fold higher as compared with conventional RT-PCR (Fig. 4). Subsequent to the optimization of primer concentration, reaction temperature and template amount, culture soups of 11 PPRVs isolates, grown in CHS-20 cells, were detected by RT-LAMP. These cultures yielded amplification curves that climbed maximally up to

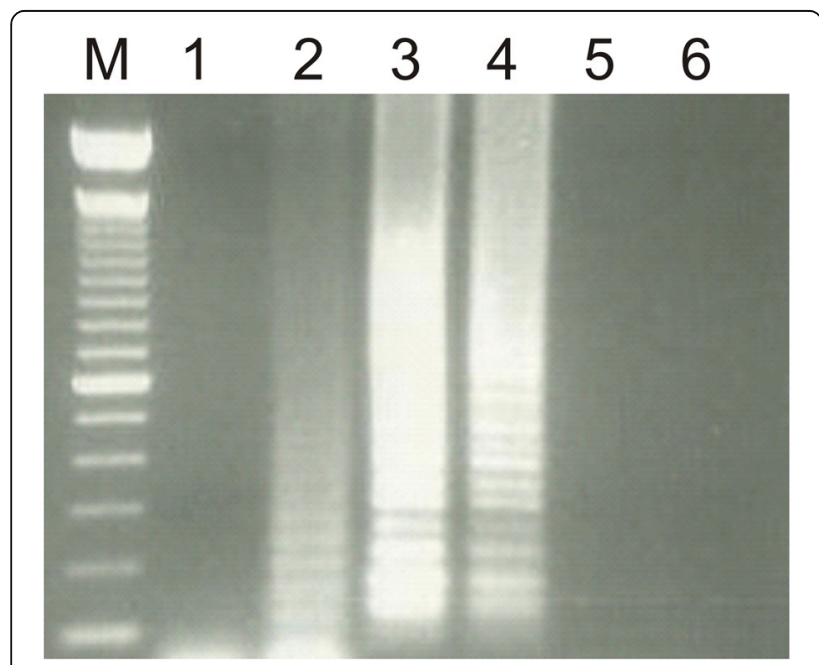

Fig. 2 Gradient of incubation temperatures for N-gene based RT-LAMP assay. Lane 1: $50{ }^{\circ} \mathrm{C}$; Lane $2: 53^{\circ} \mathrm{C}$; Lane $3: 55^{\circ} \mathrm{C}$; Lane $4: 58^{\circ} \mathrm{C}$; Lane 5: $60^{\circ} \mathrm{C}$; Lane $6: 62^{\circ} \mathrm{C}$. Precise amplification intensity was achieved at $58^{\circ} \mathrm{C}$
$60-75 \mathrm{mV} / \mathrm{min}$ well above the $30 \mathrm{mV} / \mathrm{min}$ threshold during the LAMP reaction, indicating positive detection of PPRVs with a Td value of 30 or less than 30 min (Table 1, Fig. 5).

\section{Colorimetric and fluorimetric detection of RT-LAMP products}

SYBR green staining of RT-LAMP products resulted in a colour change, observable by naked eye, from orange to light green in case of positive reaction mixtures while the negative reaction mixture remains orange (Fig. 6). Upon UV light excitation, positive reaction products produced strong bright green fluorescence while negative control depicted slight background fluorescence (Fig. 6). These observations were in accordance with those of the gel electrophoresis as a ladder-like pattern of amplified DNA product was visualized in case of positive reactions while it was absent in case of negative control reactions (Fig. 6, Additional file 3).

\section{Robustness and specificity of RT-LAMP assay for detection} of PPRV in experimentally inoculated animals

An equivalent of each swab extract collected, from experimentally inoculated goat and sheep, at 2, 4, 8, 10, 12, 14 day post-inoculation (dpi) was analyzed with RT-LAMP and RT-PCR to determine the relative robustness and sensitivity of RT-LAMP assay. During the course of experimental infection, RT-LAMP detected PPRV genome in the nasal secretions of goat from 2-dpi to 14-dpi (Table 2). It was, however, detected only on day-10 and 12 post-inoculation in sheep. The remaining samples did not produce amplification curves reaching beyond threshold limit of $>30 \mathrm{mV}$ increase in signal strength per minute and therefore, were considered as negative. In comparison to RT-LAMP, RT-PCR detected PPRV in the nasal discharges on 4-dpi to 14-dpi in the goat, whilst only on 10-dpi in sheep (Table 2, Additional file 4). Depending on the viral load, it was observed that RT-LAMP assay was able to detect the virus in the secretions of goat with $\mathrm{Td}$ 

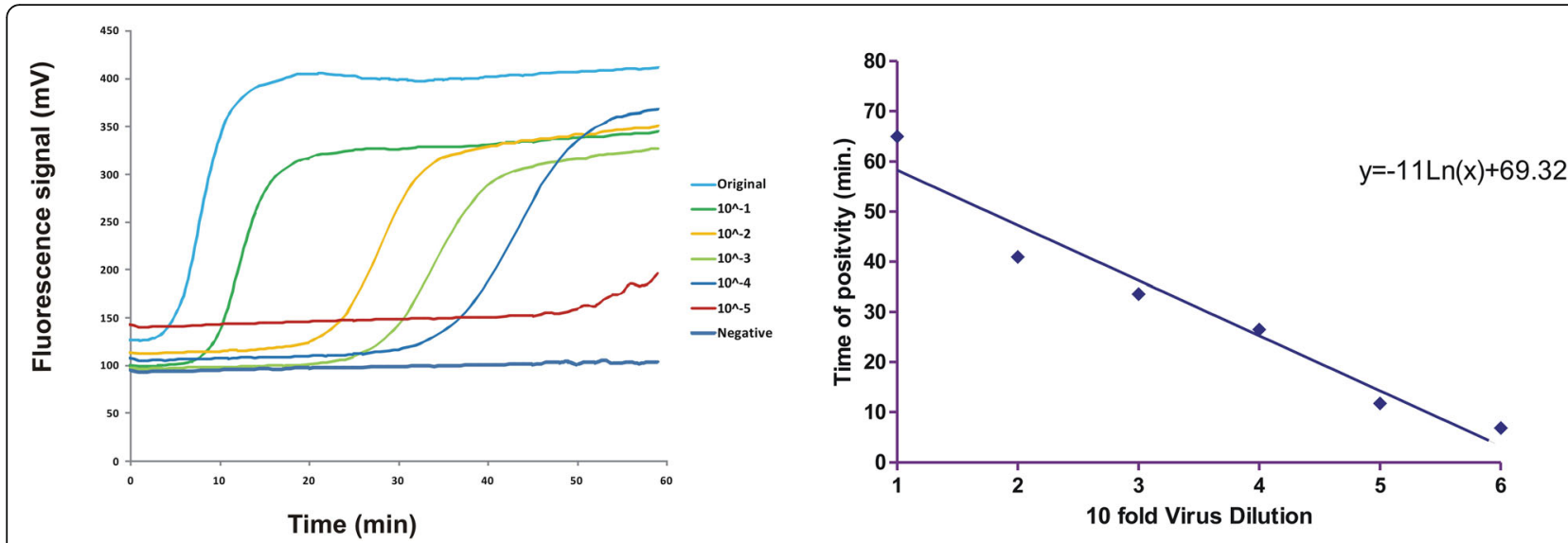

Fig. 3 Sensitivity of N-gene based RT-LAMP assay. Fluorimetric curves in RT-LAMP assay were obtained from 10-fold Serial dilutions of fluid supernatant taken from cultured PPRV in CHS-20 cells harvested at appearance of 80\% cytopathic effects. The test was able to detect dilution up to $10^{-4}$ within 60 min. Dilution $10^{-5}$ was detectable only after one hour

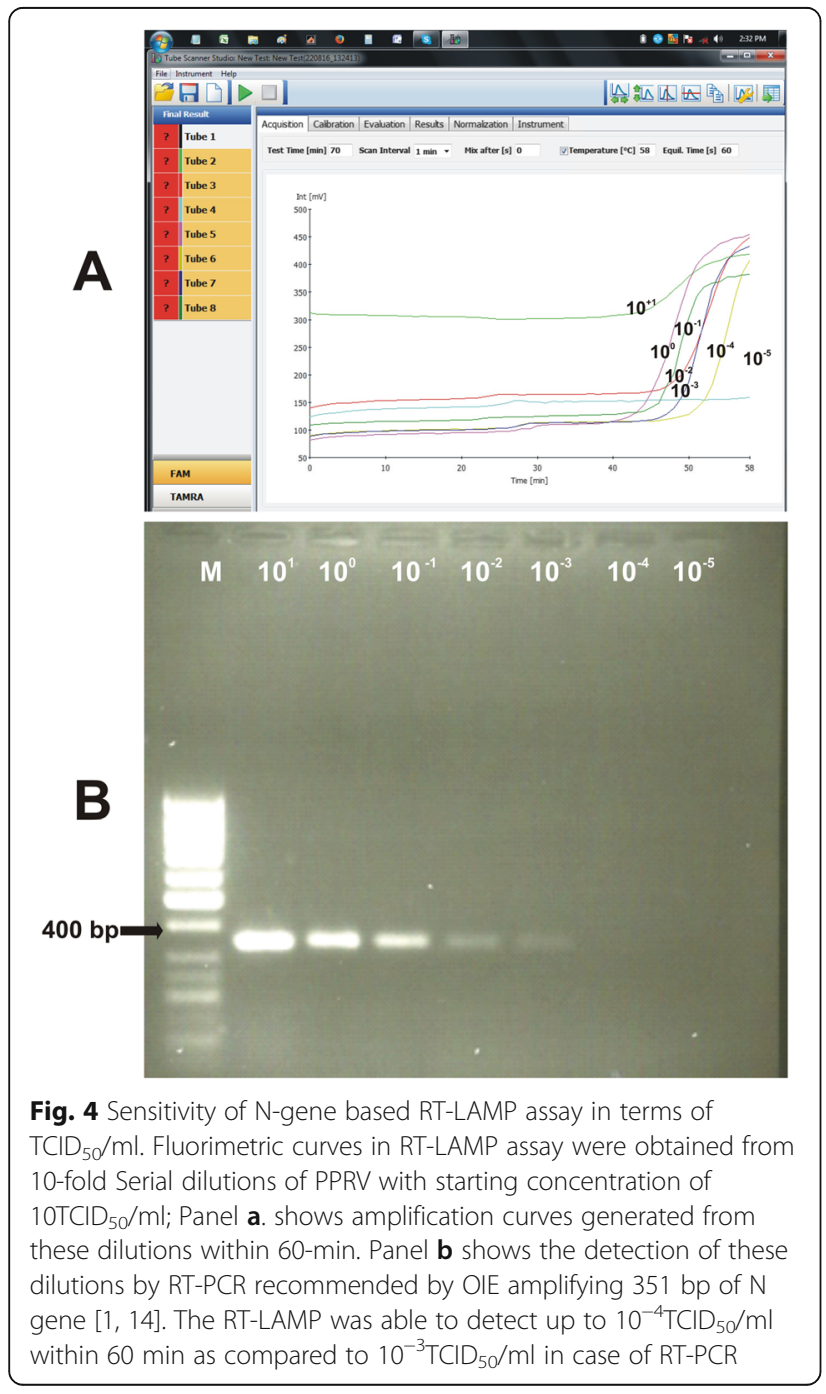

value of 23 to 40 min which were equivalent to range of ct value of 31.5-36.4 as observed in RT-qPCR (Table 3). However, the pre-requisites of RNA extraction and cDNA synthesis in case of real-time RT-PCR made it take 76.5$80.3 \mathrm{~min}$ for the detection of these samples (Table 3, Additional files 5 and 6). RT-LAMP was found to be more robust than RT-qPCR by taking at least forty fewer minutes for detecting PPRV in these samples.

\section{Detection of PPRV in the animals affected in suspected outbreaks}

A total of 32 nasal swabs collected from goats in field outbreaks at three districts of Punjab were subjected to the optimized RT-LAMP protocol along with positive and negative controls (Table 4). For threshold validation, only those samples were considered positive that produced amplification curve beyond $30 \mathrm{mV}$ detection limit. Among the clinical samples, nineteen yielded an amplification curve with a $\mathrm{Td}$ value of $25-50$ min (Table 4). However, thirteen clinical samples along with negative controls that consisted of measles and canine distemper viruses did not yield any amplification signal or a signal below threshold limit. In order to evaluate the sensitivity and robustness of RT-LAMP assay, equivalent set of the swabs was subjected to the conventional RT-PCR using N protein gene specific primers that generated a PCR fragment of $\sim 450 \mathrm{bp}$ in case of positive samples. Conventional RT-PCR detected PPRV in seventeen samples. These results indicated that RTLAMP assay is somewhat as specific as the conventional RT-PCR assay; however, RT-LAMP detected PPRV in two more samples than RT-PCR. Comparatively, RT-LAMP was more robust in nature as it allowed quick detection of PPRV infection within $60 \mathrm{~min}$ as compared to $4-5 \mathrm{~h}$ in case of conventional RT-PCR that requires separate RNA extraction, cDNA synthesis, PCR and gel electrophoresis 
Table 1 PPRVs isolated from clinical samples by cell culture method from four district of Punjab Province of Pakistan and detected by RT-LAMP. Time points of detection (Ct values) of cultured PPRVs in RT-LAMP assay ranged from 12 to 30 min

\begin{tabular}{llllll}
\hline $\begin{array}{l}\text { No. } \\
\text { sympe of } \\
\text { sample }\end{array}$ & Origin & $\begin{array}{l}\text { Place/year } \\
\text { of outbreak }\end{array}$ & $\begin{array}{l}\text { Cell culture } \\
\text { (CHS-20 cells) }\end{array}$ & $\begin{array}{l}\text { Td value (time point of } \\
\text { first rise in fluorescence } \\
\text { signal above threshold) }\end{array}$ \\
\hline 1 & ${ }^{\text {aNS }}$ & Sheep & DGK/2012 & + & 30 \\
2 & NS & goat & DGK/2012 & + & 12 \\
3 & NS & goat & MNW/2012 & + & 30 \\
4 & NS & goat & MNW/2012 & + & 10 \\
5 & NS & goat & MNW/2012 & + & 13 \\
6 & NS & goat & MNW/2012 & + & 14 \\
7 & NS & goat & SAH/2012 & + & 25 \\
8 & NS & goat & SAH/2012 & + & 20 \\
9 & NS & goat & SAH/2012 & + & 15 \\
10 & NS & goat & SAH/2012 & + & 12 \\
11 & NS & goat & CHK/2012 & + & 21 \\
\hline
\end{tabular}

+, Each isolate name includes sample ID, acronym of the district of sampling and year, DGK DG Khan, MNW Mianwali, CHK Chakwal, SAH Sahiwal. nd not determined. ${ }^{a} N S$ nasal swab

steps. RT-qPCR detected PPRV in $n=19$ clinical samples by with $\mathrm{Ct}$ values of 22.2 to 33.5 (Fig. 7, Table 4, Additional files $7,8,9,10,11,12$ and 13). As all the samples that were positive in RT-qPCR were also positive in RT-LAMP, both tests were equally sensitive in the detection of PPRV.

\section{Discussion}

The overall aim of this research was to develop a reliable and cost-effective diagnostic test for on-site detection of peste des petits ruminants virus (PPRV) infection in sheep and goats based on LAMP technology that might serve as a foundation for the development of point of care diagnostic tests for different infectious diseases of livestock prevalent in Pakistan. We selected PPR disease to start with on the basis of two reasons viz. i) economic significance, ii) close relevance to its prototype, Riderpest (cattle plague) that has been effectively eradicated from the face of the earth. Current diagnostic tests for PPR involve the use of immunoassays to detect the antibodies against PPRV, virus isolation using adaptable cell lines and PPRV genome detection using RT-PCR or Real Time RT-PCR [13-18]. However, these techniques require costly equipment and highly trained manpower that render these tests unsuitable for on-site application.

Recently, LAMP based diagnostic tests have been developed for various viral diseases (PPR, Avian Influenza, FMDV) [24-26]. Although, these tests are relatively inexpensive and robust in nature yet challenges associated with LAMP technology including template preparation protocols (RNA extraction and cDNA synthesis) need consideration to take it to the point of care diagnostics. Our protocol involves the use of a sample buffer that can precipitate out virus envelope and capsid proteins through ammonium sulphate precipitation and exposes viral RNA, present in the clinical sample, for its subsequent amplification through LAMP reaction. Hitherto, $\mathrm{N}$ gene mRNAs are preferred target for molecular detection of PPRV because it is the most abundantly transcribed viral gene in all morbilliviruses [14, 27]. Hence, in this test, highly conserved region at the $5^{\prime}$ end of nucleocapsid gene specific to PPRV was targeted for primer designing to ensure specificity and sensitivity (Fig. 8). For an unknown reason, we found this protocol more effective for PPRV detection in fresh samples (cell culture supernatants, swab extracts) as compared to previously stored samples that had undergone many freeze-thaw cycles.

The monitoring system of ESE Quant tube scanner provided the ease of spatio-temporal curve analysis

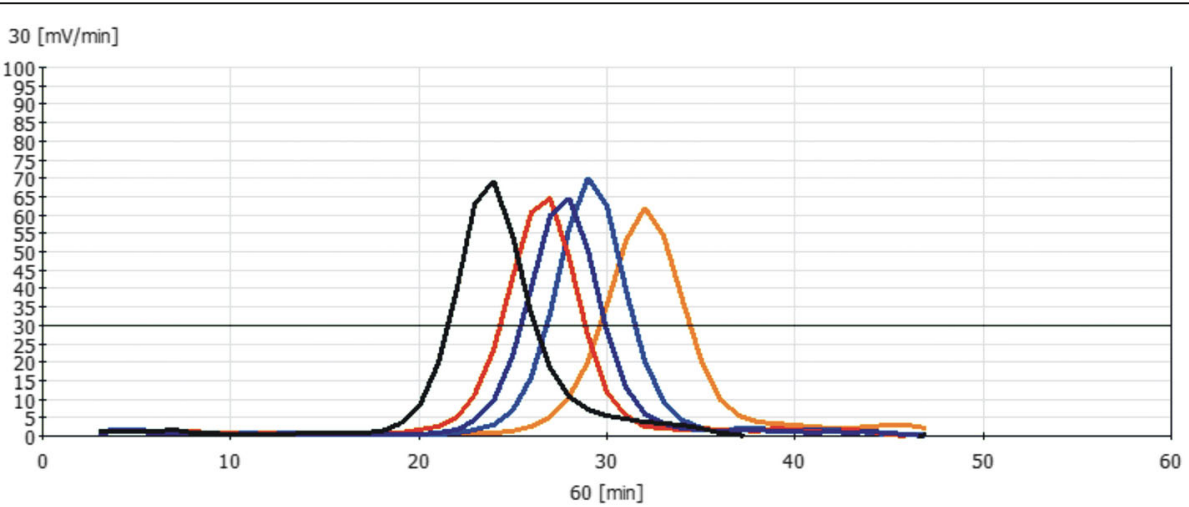

Fig. 5 Threshold validation of positive reaction in RT-LAMP assay. The amplification curves shown in the figure were produced in the assay from culture supernatants of PPRVs. The curves were generated in response to change in fluorescence signal per minute during RT-LAMP assay by ESE Quant tube scanner software. According to threshold validation, amplification curves in positive reactions increased above threshold value of $30 \mathrm{mV}$ per minute (indicated by horizontal line) 


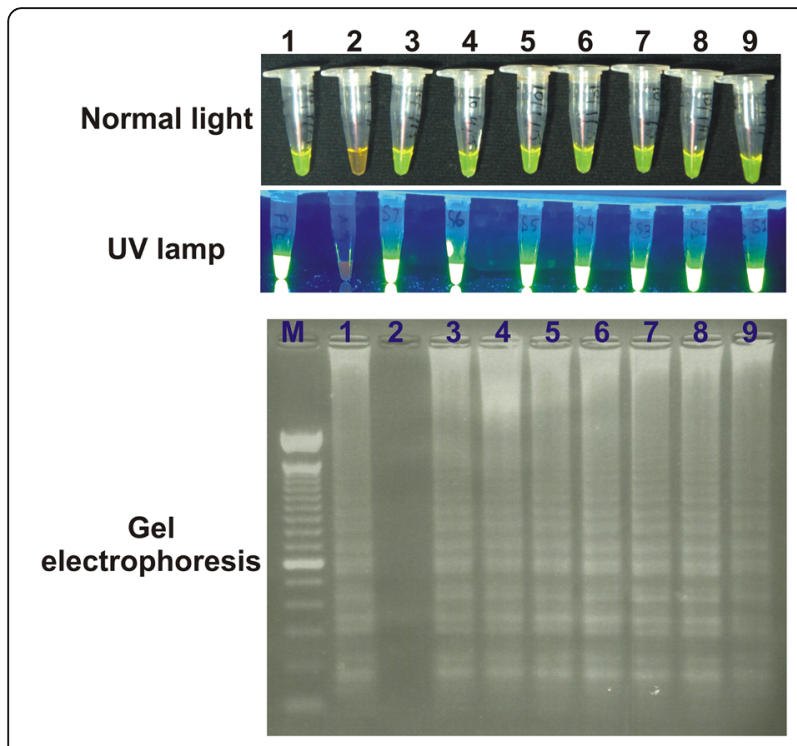

Fig. 6 Visualization of RT-LAMP assay in normal light, Ultra Violet (UV) light and analysis by gel electrophoresis. Normal light: 1, positive reaction (green); 2, negative reaction (orange); UV light: 1, positive reaction (bright green fluorescent); 2 , negative reaction (non-fluorescent). Gel electrophoresis: 1, positive reaction (ladder); 2, negative reaction (blank). 3 to 9 are positive clinical samples (same pattern as positive reaction)

during the RT-LAMP reaction. Accordingly, the test can be used even in worse field conditions where electricity is not available and transportation facilities are inadequate. To ensure specificity while maintaining high sensitivity, an algorithm is incorporated into the tube scanner software that allows threshold validation of the amplification curve to consider it as positive only if the increase of signal (slope) above the mean of the baseline is $>30 \mathrm{mV}$ for at least 3 consecutive measurements. This method of curve validation adds to the confidence of RT-LAMP result and, therefore, is more reliable than gel-electrophoresis and colorimetric analysis. By doing so, all seven samples of experimentally infected goat and only two out of total of seven samples of sheep, collected

Table 2 Comparison of conventional RT-PCR and RT-LAMP in terms of detection of PPRV in nasal secretions

\begin{tabular}{|c|c|c|c|c|c|c|c|c|c|}
\hline \multirow[t]{2}{*}{ Species } & \multirow{2}{*}{$\begin{array}{l}\text { Type of } \\
\text { test }\end{array}$} & \multicolumn{7}{|c|}{ Days post inoculation } & \multirow{2}{*}{$\begin{array}{l}\text { Total } \\
\text { no. of } \\
\text { positive } \\
\text { samples }\end{array}$} \\
\hline & & 2 & 4 & 6 & 8 & 10 & 12 & 14 & \\
\hline \multirow[t]{2}{*}{ Goat } & RT-PCR ${ }^{a}$ & - & + & + & + & + & + & + & 6 \\
\hline & RT-LAMP & + & + & + & + & + & + & + & 7 \\
\hline \multirow[t]{2}{*}{ Sheep } & RT-PCR & - & - & - & - & + & - & - & 1 \\
\hline & RT-LAMP & - & - & - & - & + & + & - & 2 \\
\hline
\end{tabular}

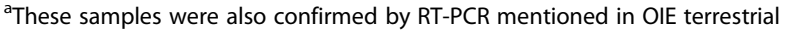
Manual [1]
Table 3 Comparison of robustness of RT-LAMP assay with real-time RT-PCR for detection of PPRV in nasal swab samples collected on alternative days from experimentally infected goat

\begin{tabular}{lllc}
\hline $\begin{array}{l}\text { Day post } \begin{array}{l}\text { inoculation } \\
\text { (dpi) }\end{array} \\
2\end{array}$ & $\begin{array}{l}\text { Detection } \\
\text { time }(T d) \text { in } \\
\text { RT-LAMP }\end{array}$ & \multicolumn{2}{l}{ Real-time RT-PCR } \\
\cline { 3 - 4 } & 39.5 & 36.4 & $\begin{array}{l}\text { Total time to reach } \\
\text { Ct (minutes) }\end{array}$ \\
\hline 4 & 23 & 31.5 & 70.33 \\
6 & 39 & 34.5 & 76.5 \\
8 & 37 & 34.7 & 78.7 \\
12 & 40 & 34.2 & 78.9 \\
\hline
\end{tabular}

aTotal time includes RNA extraction + CDNA synthesis $(50 \mathrm{~min})+$ time to reach ct value in real-time PCR steps (50 s per cycle)

on alternative days for a period of two weeks, were considered as positive. Because all the samples that were positive by RT-PCR was also positive in RT-LAMP, RTLAMP was rather as specific as conventional RT-PCR. Nonetheless, RT-LAMP detected PPRV in these samples 4-5 h earlier than RT-PCR. Comparative sensitivity $(100 \%)$ of the RT-LAMP with RT-qPCR was assured by the fact that both detected nineteen clinical samples, collected in field outbreaks; while conventional RT-PCR (89.5\% sensitive) could not detect PPRV in two samples that were positive both in RT-LAMP and RT-qPCR. The specific detection of RT-LAMP can be attributed to its intrinsic stringency by single small fragment $(\approx 200-250 \mathrm{bp})$ simultaneously by utilizing six primers, while the large amount of DNA produced during the reaction ensures high sensitivity [22-26]. LAMP can multiply the target DNA $10^{9}$ to $10^{10}$ times the starting amount and detect 0.01 to 10 plaque-forming units (pfu) of viral particles [28]. The sensitivity of the RT-LAMP developed in this study is comparable to previously reported LAMP assays targeting either $\mathrm{M}$ or $\mathrm{N}$ gene for the detection of PPRV $[24,29]$. In our study, RT-LAMP assay was10-fold more sensitive (detection limit of $0.0001 \mathrm{TCID}_{50} / \mathrm{ml}$ ) and $3-4$ times more robust than conventional-RT-PCR with a detection limit of $0.001 \mathrm{TCID}_{50} / \mathrm{ml}$ as reported by Couacy-Hymann et al. [14]. Previous protocols of LAMP, however, have used extracted RNA for subsequent synthesis of cDNA prior to its amplification by LAMP. The essential steps of RNA extraction and its reverse transcription require a sophisticated laboratory environment and increase the time of detection. The leading benefit of the RT-LAMP developed in this study for the detection of genome of PPRV directly by using the virus culture supernatant or clinical samples as such without a need for separate RNA extraction and/or cDNA synthesis ensure its application in the field. Due to the added benefits of higher sensitivity, robustness and simplicity, $\mathrm{N}$ gene based RT-LAMP can be a proficient alternative to the 
Table 4 PPRV detection by RT-LAMP in clinical samples collected in outbreaks

\begin{tabular}{|c|c|c|c|c|c|c|}
\hline \multirow[t]{2}{*}{ District } & \multirow{2}{*}{$\begin{array}{l}\text { Year of } \\
\text { outbreak }\end{array}$} & \multirow{2}{*}{$\begin{array}{l}\text { Samples } \\
\text { tested }\end{array}$} & \multicolumn{2}{|l|}{ RT-LAMP } & \multirow{2}{*}{$\begin{array}{l}\text { No. positive } \\
\text { in RT-PCR }\end{array}$} & \multirow{2}{*}{$\begin{array}{l}\text { No. positive in } \\
\text { real-time RT-PCF } \\
\text { (Ct value) }\end{array}$} \\
\hline & & & Positive & Negative & & \\
\hline Mianwali & 2012 & 08 & 04 & 04 & 04 & $04(22.3-26.5)$ \\
\hline Chakwal & 2012 & 04 & 03 & 01 & 03 & $03(31.7-33.1)$ \\
\hline Sahiwal & 2014 & 20 & 12 & 08 & 10 & $12(26.2-33.3)$ \\
\hline Total (percentage) & - & 32 & 19 (59.4\%) & $13(40.6 \%)$ & 17 (59.4\%) & 19 (59.4\%) \\
\hline
\end{tabular}

conventional RT-PCR especially in open field conditions where cold chain of sample transportation and highly equipped laboratories are not available.

Under UV light, a bright green fluorescence is observed in case of positive reaction (on addition of SYBR-green). This ability of the RT-LAMP assay to differentiate between positive and negative samples can be very useful especially in the field conditions even if the tube scanner is not available. Due to the high sensitivity of the test, it can be assumed that if a test is negative by threshold validation, colorimetric analysis and gelelectrophoresis, it would be essentially negative [21-26].
A

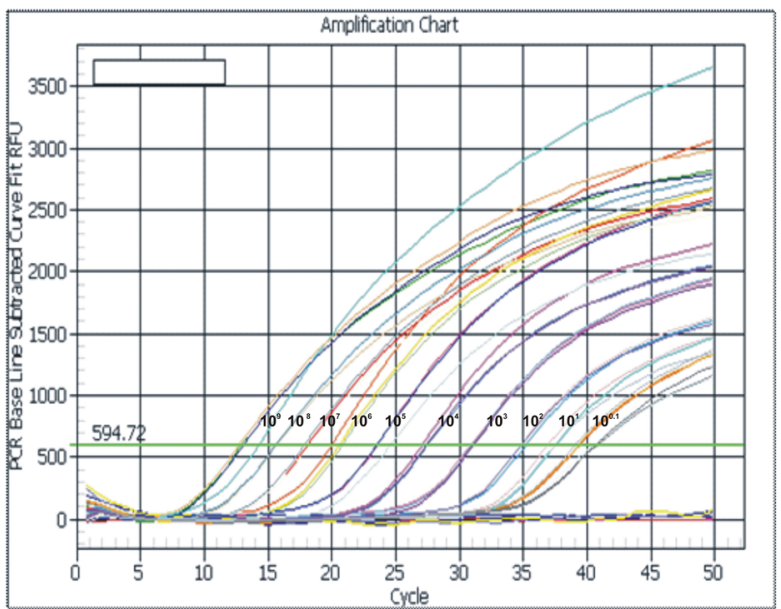

C

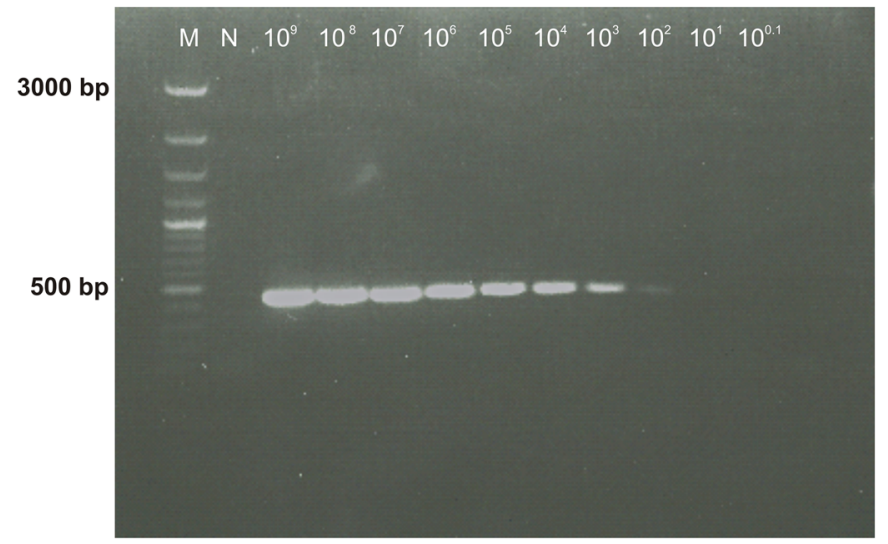

B

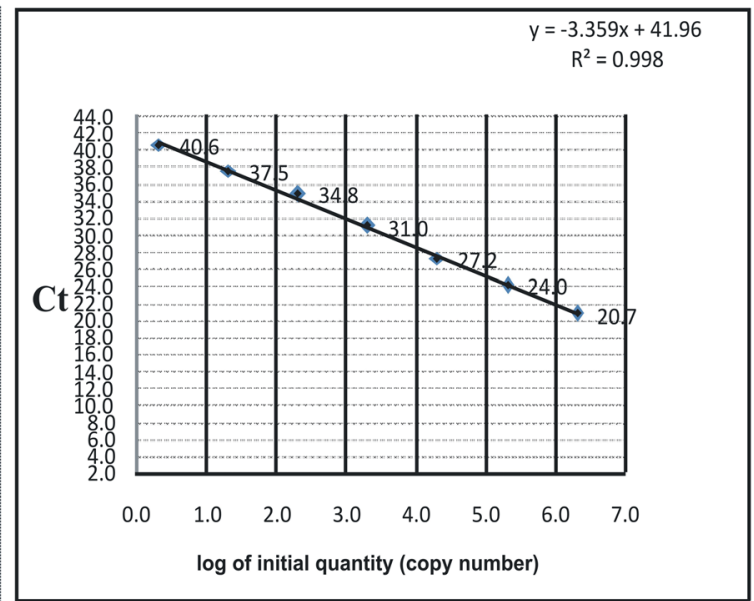

D

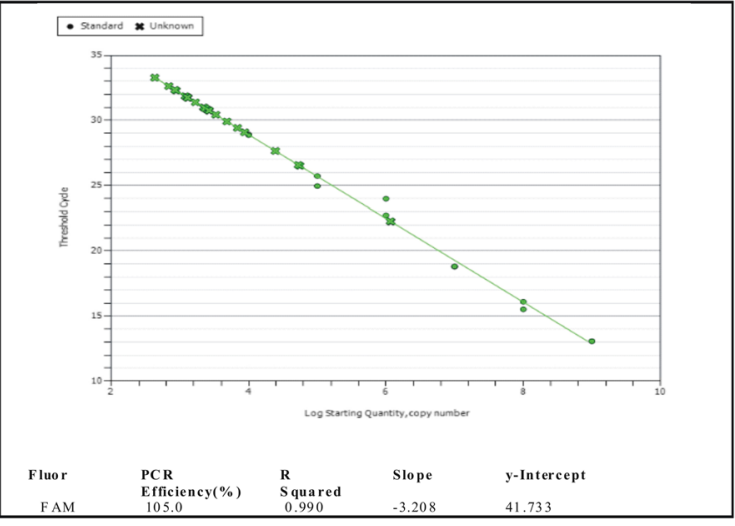

Fig. 7 Limit of detection of RT-qPCR and its application for the detection of PPRV in clinical samples; Panel $\mathbf{a}$. In the figure are shown amplification curves generated by serial dilution of cloned standard of PPRV N gene (463 bp fragment); Panel $\mathbf{b}$. For the estimation of limit of detection, threshold cycle $\left(\mathrm{Ct}\right.$ ) values of standard dilutions from $2.06 \times 10^{6}$ to $2.6 \times 10^{0}$ were drawn against log values of copy number. Limit of detection was estimated to be $\approx 20$ copies at $37.5 \pm 0.9$ cycle although $C t$ value of $40^{\text {th }}$ cycle was also detectable; Panel $\mathbf{c}$. Detection limit of RT-PCR used in this study was up to $2.06 \times 10^{2}$ copies of the plasmid; Panel $\mathbf{d}$. The threshold cycle $(\mathrm{Ct})$ values obtained by amplification of PPRV in clinical samples along with standard 


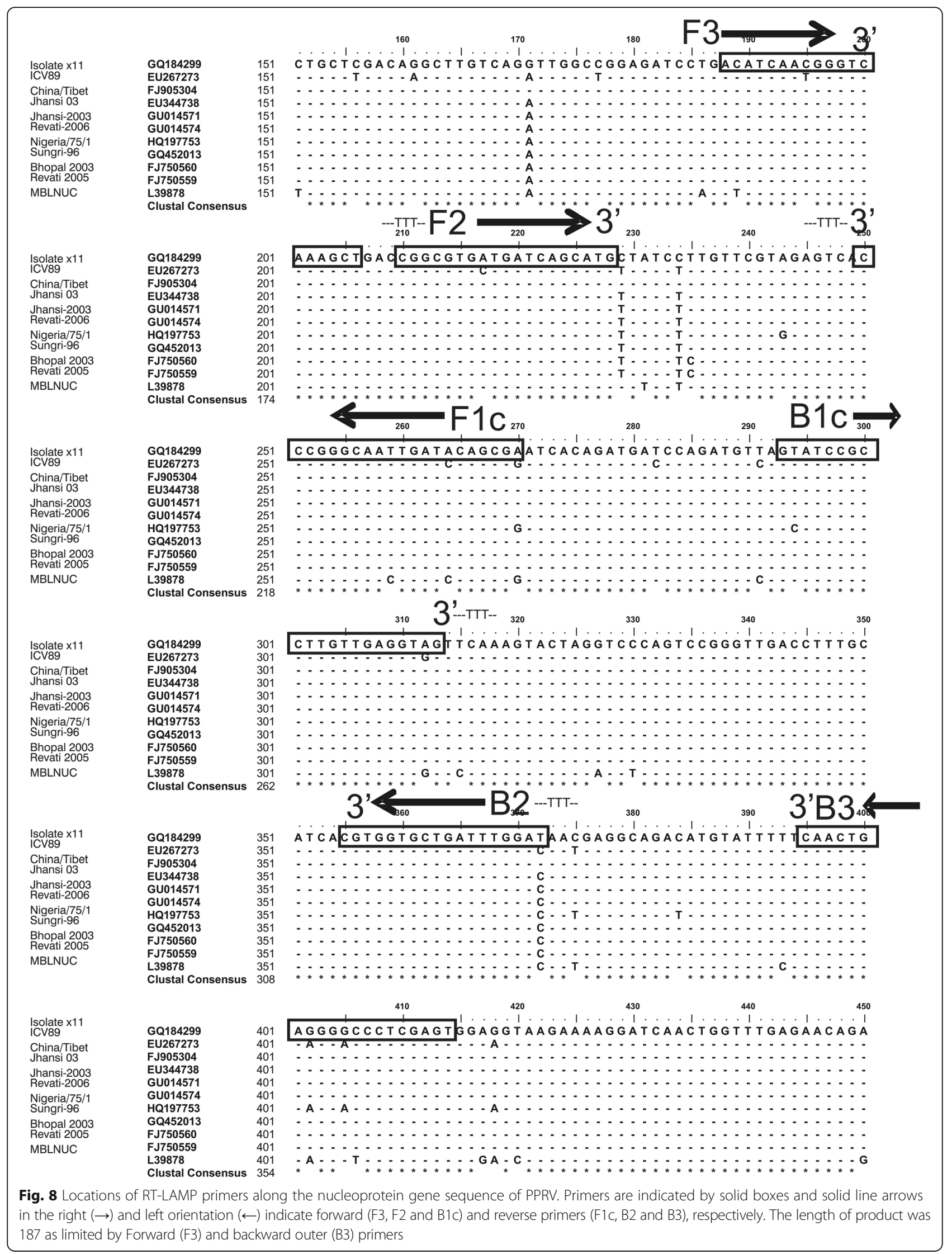


For that reason, RT-LAMP can be used for the detection of PPRV antigen in eradication campaigns to confirm the absence of disease.

The world population is experiencing continuous growth at an annual rate of $1.1 \%$ and estimated to reach 9.1 billion by 2050 [30]. Keeping it in the view, The Food and Agriculture Organization (FAO) of the United Nations estimates that the overall food production will need to increase by $70 \%$ in order to feed this projected world population thereby increasing pressure on the livestock sector to meet the growing demand for high value animal protein. Along with developed countries, where maximum livestock potential is already being utilized, developing countries like Pakistan, which have a lot of unexplored potential for livestock, need to contribute towards global food security. In these countries, there are certain challenges faced by livestock sector to cope up with these needs, among those, infectious diseases remain a key constraint and must be controlled for efficient livestock production. Accordingly, successful disease control or eradication program should be launched that would mainly rely on the prophylactic measures, surveillance \& monitoring methods as well as the efficacy \& robustness of the diagnostic tests. LAMP based diagnostic methods have taken the lead over other costly ones for being robust, economic and sensitive. RT-LAMP, developed in this study, for robust, specific on-site diagnosis of PPRV nucleic acid under field conditions is very practicable in the disease diagnosis during eradication of PPR. It offers a unique utility in the "Global PPR Eradication Campaign" launched recently, in the year 2015, by the FAO and OIE [31].

\section{Conclusions}

These laboratory, experimental and field evaluation of the LAMP method developed in this study for the onsite diagnosis of PPR showed that it is sensitive, robust, and easy diagnostic method and can prove to be very useful to the field practitioners. These features make it an inimitably advantageous nucleic acid detection system for the confirmation of PPRV infection under the field conditions. It is a sensitive as well as stringent assay of choice for quick detection of the virus in epidemics or during regular abattoir inspections or screening programs targeting PPRV eradication.

\section{Methods}

\section{Cell lines, viruses and clinical samples}

Vaccine strain of PPRV, Nigeria 75/1 was used as a reference strain in this study. In addition to 11 cultured PPRV strains a total of 32 nasal swabs collected from goats in three suspected PPR outbreaks during 2012-2014 were evaluated for virus detection. Those suspected goats were owned by herdsmen who were well informed about the purpose of sample collection and their consent was taken prior to collection of swab samples. The virus isolation from individual samples was carried out using CHS-20 cell line (kindly provided by Dr. Adama Diallo, IAEA Laboratories, Austria) that stably express signaling lymphocyte activation molecule (SLAM), a cell surface receptor for PPRV [8].

\section{PPRV inoculation of sheep and goat}

Two animals, one goat and one sheep bought from local livestock market, at the age of 5-6 months were tested negative for the presence of antibodies against PPRV using competitive enzyme linked immunosorbent assay (cELISA) [32] and acclimatized to controlled environment for two weeks. These were also confirmed as negative for PPRV antigen by RT-PCR [33] prior to their inoculation intravenously with $1 \mathrm{ml}$ of $10^{2}\left(\mathrm{TCID}_{50}\right)$ PPRV strain 17BLK, which was isolated from a clinically infected goat in 2012 [34]. These animals were bought from local market and kept under controlled conditions at NIBGE animal house and were examined on a daily basis for the appearance of any clinical signs and symptoms up to 14 days post infection (dpi). Experimental samples including blood and nasal swabs were collected from each animal on alternate days up to $14 \mathrm{dpi}$. The samples were stored at $-80{ }^{\circ} \mathrm{C}$ until further use.

\section{Primer designing}

Full-length nucleotide sequences of $\mathrm{N}$ protein gene of lineage-IV PPRVs along with vaccine strain (Nigeria/75/1) were retrieved from the GenBank database and aligned using MegAlign 5.00, DNA star Inc., software to identify conserved regions. Analysis of the prospective target regions was performed with the LAMP primer design software (www.http://primerexplorer.jp/elamp4.0.0/) for the automated selection of the primers. A set of primers was finally selected that included an outer pair consisting of forward outer (F3) and backward outer (B3) primer, an inner pair consisting of forward inner (FIP = FIc + F2) and backward inner $(\mathrm{BIP}=\mathrm{B} 1+\mathrm{B} 2 \mathrm{c})$ primer as mentioned in Table 5 . The location of these primers on the conserved target region is shown in Fig. 8.

\section{Sample preparation and RT-LAMP reaction}

Two microliter $(2 \mu \mathrm{l})$ of swab extract or cell-culture supernatant was added to $30 \mu \mathrm{l}$ of RT-LAMP buffer (66 $\mathrm{mM}$ Tris- $\mathrm{HCl}$ pH8.8, $32 \mathrm{mM} \mathrm{KCl}, 32 \mathrm{mM}$ $(\mathrm{NH} 4)_{2} \mathrm{SO}_{4}, 16 \mathrm{mM} \mathrm{MgCl}, 0.3 \%$ (v/v) Tween 20) and incubated at room temperature for five minutes. Fifteen microliter $(15 \mu \mathrm{l})$ of this sample mixture was added to $10 \mu \mathrm{l}$ of reaction mixture providing final concentrations of $0.4 \mathrm{mM}$ dNTP, $460 \mathrm{mM}$ trehalose and 0.4X EvaGreen ${ }^{\circ}$ dye. A ready to use primer mix was added providing a final concentration of $0.25 \mu \mathrm{M}$ of each of the outer primers (F3 and B3) and $1.25 \mu \mathrm{M}$ of each of the inner 
Table $\mathbf{5} \mathrm{N}$ gene based primers set used in detection of PPRV by RT-LAMP assay

\begin{tabular}{|c|c|c|c|c|c|}
\hline Primer ID & Type & Sequence $\left(5^{\prime}\right.$ to $\left.3^{\prime}\right)$ & Position* & Length (bases) & $\begin{array}{l}\text { Predicted length of } \\
\text { amplified segment }\end{array}$ \\
\hline PPRV F3 & Forward outer & ACATCAACGGGTCAAAGCT & $295-313$ & 19 & $187 \mathrm{bp}$ \\
\hline PPRV B3 & Backward outer & ACTCGAGGGTCCTTCAGTTG & $521-502$ & 20 & \\
\hline PPRV/FIP & $\begin{array}{l}\text { Forward inner } \\
(F 1 c+F 2)\end{array}$ & CCGCTGTATCAATTGCCCGGGTITCGGCGTGATGATCAGCATG & $376-357 / 317-335$ & 44 & \\
\hline PPRV/BIP & $\begin{array}{l}\text { Backward inner } \\
(B 1+B 2 C)\end{array}$ & GCATCCGCCTTGTTGAGGTAGTITITTGTCCAAATCAGCACCACG & $400-421 / 481-462$ & 46 & \\
\hline
\end{tabular}

*The position of primers is indicated as per sequence position of complete genome of PPRV (Accession \#hq197753)

primers (FIP and BIP). Amplification of the target genome segment of PPRV based on strand displacement activity was achieved using 8 units per reaction of Bsm polymerase (FermentasThermo Scientific, St. Leon-Rot, Germany). The assay was carried out at $58{ }^{\circ} \mathrm{C}$ in an ESEQuant Tube Scanner TS95 (Qiagen, Hilden, Germany) and the increase in fluorescence signal was recorded once per minute for $60 \mathrm{~min}$.

\section{Fluorometric and gel electrophoresis based analysis of RT-LAMP products}

ESE-Quant Tube Scanner was set at 6- carboxyfluorescein $($ FAM $)$ channel $($ excitation $=487 \mathrm{~nm}$, detection $=525 \mathrm{~nm})$ for the acquisition of fluorescence data. Baseline threshold value of the amplification curve was calculated as 10 times standard deviation of the fluorescence signal during initial $5 \mathrm{~min}$. Accordingly, for evaluation of the generation of "quasi" exponential amplification phase which is an indication of a positive reaction, each sigmoidal curve was analysed for a time-point corresponding to increase in florescence signal above threshold i.e. $>30 \mathrm{mV} / \mathrm{min}$ for a minimum of 3 consecutive measurements (Fig. 5). The time of first rise in signal above threshold $(>30 \mathrm{mV} / \mathrm{min})$ was given by the detection-time (Td) value. For unaided eye evaluation, $0.2 \mu \mathrm{l}$ SYBR green fluorescent dye was added to the reaction tubes at the end of the assay. The positive reaction developed green colour while negative reaction remained orange. Furthermore, these reactions were analyzed for bright green fluorescence under UV light, which is an indication for a positive test. For agarose gel analysis, RT-LAMP products were incubated at $80{ }^{\circ} \mathrm{C}$ for 02 min to stop any residual enzymatic activity and subsequently analysed on $2 \%$ agarose gel stained with ethidium-bromide and the image was captured using a UV light transilluminator.

\section{Comparative evaluation of RT-LAMP assay with RT-PCR and/or Quantitative RT-PCR (RT-qPCR) using clinical samples}

For comparative evaluation of LAMP with reverse transcription PCR (RT-PCR), PPRV nucleic acid was detected in the clinical samples that were collected from suspected goats in field outbreaks, after taking consent from their owners, and experimentally infected animals, bought from local market and kept under control conditions, from days 1-14 post-inoculation (dpi), by these tests. The progression of disease in these infected animals was monitored by measuring the cumulative clinical score and changes in rectal temperature. After 14 days, the animals were slaughtered and observed for any pathological lesions in the organs. RT-LAMP was applied directly on swab extracts as mentioned above. For RT-PCR and RT-qPCR based detection of PPRV in these samples, total RNA was extracted from $200 \mu \mathrm{l}$ suspension of each swab-extract using TRIzol method following the manufacturer's instructions (Invitrogen, Carlsbad, USA). RNA pellet was resuspended in $20 \mu \mathrm{l}$ of RNase-free water, quantified using Nanodrop 1000 spectrophotometer, and stored at $-80{ }^{\circ} \mathrm{C}$ until further use. Total RNA $(1 \mu \mathrm{g})$ was reverse transcribed to cDNA by random hexamer primers using RevertAid ${ }^{\mathrm{TM}}$ First Strand cDNA Synthesis Kit following the manufacturer's instructions (Invitrogen, Paisley, UK). Subsequently, $2.5 \mu \mathrm{l}$ of first strand cDNA product was used as a template to amplify 463 bp fragment of nucleoprotein gene of PPRV by RT-PCR [33]. To test the sensitivity of the assay, serial dilutions of virus culture supernatants were subjected to the LAMP. For the comparative detection of PPRV genome, RNA extracted from tenfold serial dilutions ranging from $10^{0}$ to $10^{-5}$ dilution of PPRV starting from $10 \mathrm{TCID}_{50} / \mathrm{ml}$ was subjected to RT-LAMP and conventional RT-PCR recommended by OIE that amplifies a 351 bp fragment of the $\mathrm{N}$ gene of PPRV [1, 14]. Onestep RT-qPCR was carried out, in parallel with the RTLAMP assay, using the iScript One-Step RT-qPCR Kit (BioRad, Hercules, CA, USA). PPRV N-gene specific forward $\left(5^{\prime}\right.$ - ggactgggcctcgacagg- $\left.3^{\prime}\right)$ and reverse $\left(5^{\prime}\right.$-ggatcgcagctttgacttcttc- $\left.3^{\prime}\right)$ primers were used in combination with Taqman probe (FAM-5'tccttcctccagcataa3' -BHQ1) [8]. For standard curve generation, seven 10-fold dilutions $\left(10^{6}-10^{0}\right.$ copies) of a defined template (pTZ57R/T that contained partial CDS of PPRV $\mathrm{N}$ protein gene) were subjected to a 40-cycle qPCR assay along with clinical samples and no template control (NTC). The 
reaction was carried out in a total volume of $20 \mu \mathrm{l}$ (400nM of each primer, $200 \mathrm{nM}$ of the probe and $0.4 \mu \mathrm{l}$ of the iScript reverse transcriptase) using IQ5 $5^{\text {max }}$ Real-Time PCR Detection System (BioRad, USA) under the following reaction conditions: $50{ }^{\circ} \mathrm{C}$ for $10 \mathrm{~min} ; 95^{\circ} \mathrm{C}$ for 5 min and 40 cycles of $95^{\circ} \mathrm{C}$ for 10 s and $60{ }^{\circ} \mathrm{C}$ for 30 s.

\section{Additional files}

Additional file 1: Detection limit of N-gene based RT-LAMP assay. Sheet 1; The excel file includes data as values of millivolts $(\mathrm{mV}$ ) against specified time obtained from 10-fold Serial dilutions of fluid supernatant taken from cultured PPRV in CHS-20 cells harvested at appearance of $80 \%$ cytopathic effects. Sheet 2; The test was able to detect dilution up to $10^{-4}$ within $60 \mathrm{~min}$. Sheet 3; includes data generated from real-time RT-PCR by amplifying 10-fold serial dilutions of known plasmid concentrations. Sheet 4; data generated in real-time RT-PCR based detection of PPRV in clinical samples collected in field outbreaks. (XLSX $51 \mathrm{~kb}$ )

Additional file 2: Data file generated by ESE software during the detection of PPRV in the field conditions. It is only readable format by software. (DAT $29 \mathrm{~kb}$ )

Additional file 3: Amplification curves obtained by ESE quant tube scanner software during the RT-LAMP based detection of PPRV in clinical samples. The slope of positive amplification curve becomes steeper during the exponential phase and becomes horizontal platue again as the reactions components are consumed during the amplification process. (PNG $153 \mathrm{~kb}$ )

Additional file 4: ESE Software file in notepad format generated from LAMP based PPRV detection in experimentally infected goat from 2-dpi to 12-dpi. In positive samples, the value of amplification signal in the form of mVolts increased with the passage of time until a platue phase is reached with no more increase in signal. (TXT $5 \mathrm{~kb}$ )

Additional file 5: RT-qPCR in goat. File includes information on amplification of PPRV from experimentally infected goat from 2 to 14-dpi. (RTF $3678 \mathrm{~kb}$ )

Additional file 6: ESE software file in notepad format generated from Detection of PPRV in clinical samples collected in outbreaks. Again in positive samples, the value of amplification signal in the form of mVolts increased with the passage of time during exponential phase until a platue phase is reached with no more increase in signal. (TXT $5 \mathrm{~kb}$ )

Additional file 7: RT-LAMP based detection of serial dilutions of virus supernatant. The graph was generated in "GraphPad Prism software" expressing increasing serial dilution of PPRV culture supernatant along $x$-axis and corresponding time of detection along $y$-axis. The RT-LAMP was able to detect up to $10^{-4} \mathrm{TCID} 50 / \mathrm{ml}$ within $60 \mathrm{~min}$. (TXT 143 bytes)

Additional file 8: Threshold validation in clinical samples. In the field outbreaks, only those samples were taken as positive which crossed the threshold limit of 30mVolts in their amplification signals. (PNG $164 \mathrm{~kb}$ )

Additional file 9: End-point UV visualization of RT-LAMP reaction. The positive samples produced bright green fluorescence in contrast to negative control. (JPG $981 \mathrm{~kb}$ )

Additional file 10: Data file of End point report of RT-qPCR. It includes the data of end-point analysis for threshold validation of amplification curves generated during the test. (RTF $261 \mathrm{~kb}$ )

Additional file 11: Data file of RT-qPCR based detection of serial dilutions of PPR N gene standard cloned plasmid, at FAM channel. Accuracy was equivalent to $R^{2}=0.999,3.03$ as value of slope. (RTF $3659 \mathrm{~kb}$ )

Additional file 12: Data file of RT-qPCR based detection of PPRV in clinical samples collected in field outbreaks. In these samples, ct values ranged from 22 to 33. (RTF $3690 \mathrm{~kb}$ )

Additional file 13: RT-PCR based detection of PPRV in blood of experimentally infected sheep and goat. Corresponding wells for Goat (G) and Sheep $(S)$ are indicated in the figure along with respective number of day post inoculation (dpi). In goat virus detectable from 4-dpi to 14-dpi. (JPG 821 kb)

\section{Abbreviations}

ASSURED: Affordable sensitive specific user-friendly robust equipment free deliverable to the end user; BIP: Backward inner primer; Bsm: Bacillus smithii; Bst: Bacillus stearothermophilus; cDNA: Complimentary DNA; cELISA: Competitive enzyme linked immunosorbent assay; CHS-20: Monkey kidney cells expressing sheep signaling lymphocyte activation molecule; dpi: Day post inoculation; FAM: 6- carboxyfluorescein; FAO: The Food and Agriculture Organization of the United Nations; FIP: Forward inner primer; FMDV: Foot and mouth disease virus; mV: Milli Volts; N: Nucleocapsid gene; NTCs: No template controls; OIE: The World Organization for Animal Health; PPR: Peste des petits ruminants; PPRV: Peste des petits ruminants virus; RT-LAMP: Reverse transcription-loop mediated isothermal amplification assay; RT-PCR: Reverse transcription polymerase chain reaction; TCID50/ml: Tissue culture infective dose-50 per ml; Td: Detection time

\section{Acknowledgements}

I would also recognize Dr Imran Amin for helping in real-time PCR experiments and Dr. Wasim Abbas (Senior Scientist, (Virology/Immunology) at Environmental Biotechnology Division, NIBGE) for reviewing the draft. I would like to acknowledge field veterinarians who informed about the suspected animals and helped during sampling (Dr Zafar lqbal (VO, Rahim Yar khan), Dr M. IIfan Alvi (VO, District Qabola), Dr Sajjad Haider (VO, District Qabola), Dr M. Imran (VO, District Chakwal), Dr M. Sajjad (SVO, District DG Khan), Dr Agha Shafique, (VO, District DG Khan), Mr. Jamrood Khan (Mianwali).

\section{Funding}

This research was funded by International Atomic Energy Agency (IAEA) through Coordinated Research Program IAEA/CRP, Contract No. 14567 and International Research Support Initiative Program (IRSIP) of the Higher Education Commission, Pakistan.

\section{Availability of data and materials}

All the data sets on which the conclusions of the paper rely are either presented in the main paper or included in the additional supporting files in the form of spreadsheets/data files/actual snapshots generated from software.

\section{Authors' contribution}

WA Conceived and designed the experiments and primers, performed the experiment, Analyzed the data, Wrote the paper. HU Supported primer design and contributed reagents, analyzed the data, reviewed the manuscript. SH Performed the experiments and collected the data. AM Maintained the care at animal house, helped in collection of samples, arranged field samples. MF Analyzed the data, Wrote the paper. MA Maintained the care and handling of experimental animals, collection of field samples. QMK Contributed reagents/ materials, evaluated the design of the experiments, data analysis and reviewed the manuscript. All authors read and approved the final manuscript.

\section{Authors' information}

Ashraf W. is PhD from Biotechnology Campus (NIBGE) of Pakistan Institute of Engineering and Applied Sciences (PIEAS) and involved in research on molecular detection and evolutionary phylogenetics of PPRV since 2009. He did part of his PhD studies on partial as well as full genome sequences and evolutionary phylogeny of PPRV from Pakistan, Ghana and Benin. He has future plans to continue his research on molecular diagnosis and vaccine development and genetic studies of host- viral pathogen interaction. Dr. Khan Q. M. (corresponding author) is involved in molecular diagnostics and evolutionary genetics of transboundary animal diseases of Rinderpest, PPR, FMD, Avian Influenza and Brucellosis since last twenty years and has actively participated in Rinderpest eradication and successfully completed Co-ordinated research projects (CRP) on Early and Sensitive Detection of PPRV in collaboration with Dr Herman Unger and Dr Adama Diallo at IAEA.

\section{Competing interests}

The authors declare that they have no competing interests.

Consent for publication Not Applicable. 


\section{Ethics approval and consent to participate}

The study design and protocols for experimental goat and sheep were approved by "The Ethical Committee, National Institute for Biotechnology and Genetic Engineering" and "Animal House Committee, National Institute for Biotechnology and Genetic Engineering (NIBGE), P.O. Box: 577, Jhang road, Faisalabad, Pakistan" prior to the start of the study (ISO\#08/01/2015). Experimental animals [sheep; Kajla breed and goat; Beetle breed] were purchased from local market and kept under control conditions, provided with adequate resources for illumination, thermoregulation, ventilation and bedding of fine wood husk to maintain temperature range of $20-25^{\circ} \mathrm{C}$ and $60-70 \%$ relative humidity; water, feed and fodder were offered ad libitum. These were acclimatized to the control conditions for two weeks prior to start of experiment. Adherence to high standard of animal handling and care for experimental animals was assured during the study. The experimental animals were euthanized at the end of the study. From the sick goats in herds suspected for PPR outbreaks, swabs were collected with the prior consent of their owners.

\section{Author details}

'National Institute for Biotechnology and Genetic Engineering (NIBGE), Faisalabad, Pakistan. ${ }^{2}$ Pakistan Institute of Engineering and Applied Sciences (PIEAS), Islamabad, Pakistan. ${ }^{3}$ Animal Production and Health Section, Joint FAO/IAEA Division of Nuclear Techniques in Food and Agriculture, Vienna, Austria.

Received: 7 April 2016 Accepted: 24 December 2016 Published online: 25 January 2017

\section{References}

1. In Manual of diagnostic tests and vaccines for terrestrial animals 2013, Peste des petits ruminants, World Organisation for Animal Health (Office International des Épizooties: OIE) Chapter 2.7.10, page\#5-7. (Dowloaded on 05-01-2016). http://www.oie.int/fileadmin/Home/eng/Health_standards/ tahm/2.07.10_PPR.pdf.

2. Dhar P, Sreenivasa BP, Barrett T, Corteyn M, Singh RP, Bandyopadhyay SK Recent epidemiology of peste des petits ruminants virus (PPRV). Vet Microbiol. 2002;88:153-9. doi:10.1016/s0378-1135(02)00102-5.

3. Abubakar M, Jamal SM, Arshed MJ, Hussain M, Ali Q. Peste des petits ruminants virus (PPRV) infection; its association with species, seasonal variations and geography. Trop Anim Health Prod. 2009;41:1197-202. doi:10.1007/s11250-008-9300-9.

4. Zahur AB, Ullah A, Hussain M, Irshad H, Hameed A, Jahangir M, Farooq MS Sero-epidemiology of peste des petits ruminants (PPR) in Pakistan. Prev Vet Med. 2011;102:87-92. doi:10.1016/j.prevetmed.201.06.011.

5. Abu-Elzein EME, Hassanien MM, Alfaleq Al, Abd-Elhadi MA, Housawi FMI. Isolation of PPR virus from goats in Saudi Arabia. Vet Rec. 1990;127:309-10. [PubMed]: https://www.ncbi.nlm.nih.gov/pubmed/2238415.

6. Diallo A, Minet C, Le Goff C, Berhe G, Albina E, Linbeau G, Barrett T. The threat of peste des perits ruminants: progress in vaccine development for disease control. Vaccine. 2007;26:5591-7. doi:10.1016/j.vaccine.2007.02.013.

7. Couacy-Hymann E, Bodjo SC, Danho T, Koffi MY, Libeau G, Diallo A. Early detection of viral excretion from experimentally infected goats with peste-des-petits ruminants virus. Prev Vet Med. 2007;78:85-8. doi:10.1016/j. prevetmed.2006.09.003

8. Adombi CM, Lelenta M, Lamien CE, Shamaki D, Koffi YM, Traore A, Silber R, Couacy-Hymann E, Bodjo SC, Djaman JA, Luckins AG, Diallo A. Monkey CV1 cell line expressing the sheep-goat SLAM protein: a highly sensitive cell line for the isolation of peste des petits ruminants virus from pathological specimens. J Virol Methods. 2011;173:306-13. doi:10. 1016/j.jviromet.2011.02.024.

9. Bailey D, Banyard A, Dash P, Ozkul A, Barrett T. Full genome sequence of peste des petits ruminants virus, a member of the Morbillivirus genus. Virus Res. 2005;110:119-24. doi:10.1016/j.virusres.2005.01.013.

10. Nanda SK, Baron MD. Rinderpest virus blocks type I and type II interferon action: role of structural and nonstructural proteins. J Virol. 2006;80:7555-68. doi:10.1128/jvi.02720-05.

11. Chard LS, Bailey DS, Dash P, Banyard AC, Barrett T. Full genome sequences of two virulent strains of peste-des-petits ruminants virus, the Côte d'Ivoire1989 and Nigeria 1976 strains. Virus Res. 2008;136:192-7. doi:10.1016/j.virusres.2008.04.018.
12. Muthuchelvan D, Sanyal A, Balamurugan V, Dhar P, Bandyopadhyay SK. Sequence analysis of the nucleoprotein gene of Asian lineage peste des petits ruminants vaccine virus. Vet Res Commun. 2006;30:957-63. doi:10.1007/s11259-006-3407-0.

13. Libeau G, Diallo A, Colas F, Guerre L. Rapid differential diagnosis of rinderpest and peste des petits ruminants using an immunocapture ELISA. Vet Rec. 1994;134:300-4. doi:10.1136/vr.134.12.300.

14. Couacy-Hymann E, Roger F, Hurard C, Guillou JP, Libeau G, Diallo A. Rapid and sensitive detection of peste des petits ruminants virus by a polymerase chain reaction assay. J Virol Methods. 2002;100:17-25. doi:10.1016/s0166-0934(01)00386-x.

15. Parida S, Muniraju M, Mahapatra M, Muthuchelvan D, Buczkowski H, Banyard AC. Peste des petits ruminants. Vet Microbiol. 2015;181:90-106. doi:10.1016/ j.vetmic.2015.08.009

16. Barrett T. Morbillivirus infections, with special emphasis on morbilliviruses of carnivores. Vet Microbiol. 1999;69:3-13. doi:10.1016/s0378-1135(99)00080-2.

17. Singh RP, Sreenivasa BP, Dhar P, Shah LC, Bandyopadhyay SK. Development of a monoclonal antibody based competitive-ELISA for detection and titration of antibodies to peste des petits ruminants (PPR) virus. Vet Microbiol. 2004;98:3-15. doi:10.1016/j.vetmic.2003.07.007.

18. Toplu N, Oguzoglu TC, Albayrak H. Dual infection of fetal and neonatal small ruminants with border disease virus and peste des petits ruminants virus (PPRV): neuronal tropism of PPRV as a novel finding. J Comp Pathol. 2012;146:289-97. doi:10.1016/j.jcpa.2011.07.004.

19. Morshed MG LM, Jorgensen D, Isaac-Renton JL. Molecular methods used in clinical laboratory: prospects and pitfalls. FEMS Immunol Med Microbiol. 2007;49:184-91. doi:10.1111/j.1574-695x.2006.00191.x.

20. Mabey D, Peeling RW, Ustianowski A, Perkins MD. Diagnostics for the developing world. Nat Rev Microbiol. 2004;2:231-40. doi:10.1038/nrmicro841.

21. Peeling RW, Mabey D. Point-of-care tests for diagnosing infections in the developing world. Clin Microbiol Infect. 2010;16:1062-9. doi:10.1111/j.14690691.2010.03279.x

22. Nagamine K, Hase T, Notomi T. Accelerated reaction by loop-mediated isothermal amplification using loop primers. Mol Cell Probes. 2002;16:223-9. doi:10.1006/mcpr.2002.0415.

23. Njiru ZK. Loop-Mediated Isothermal Amplification Technology: Towards Point of Care Diagnostics. PLoS Negl Trop Dis. 2012;6:1-4. doi:10.1371/ journal.pntd.0001572.

24. Lin L, Bao J, Wu X, Wang Z, Wang J. Rapid detection of peste des petits ruminants virus by a reverse transcription loop-mediated isothermal amplification assay. J Virol Methods. 2010;170:37-41. doi:10.1016/j.jviromet. 2010.08.016

25. Nemoto M, Yamanaka T, Bannai H, Tsujimura K, Kondo T, Matsumura T. Development and evaluation of a reverse transcription loop-mediated isothermal amplification assay for H3N8 equine influenza virus. J Virol Methods. 2011;178:239-42. doi:10.1016/j.jviromet.2011.07.015.

26. Yamazaki W, Mioulet V, Murray L, Madi M, Haga T, Misawa N, Horii Y, King DP. Development and evaluation of multiplex RT-LAMP assays for rapid and sensitive detection of foot-and-mouth disease virus. J Virol Methods. 2013;192:18-24. doi:10.1016/j.jviromet.2013.03.018.

27. Kwiatek O, Ali YH, Saeed IK, Khalafalla Al, Mohamed OI, Obeida AA, Abdelrahman MB, Osman HM, Taha KM, Abbas Z, El Harrak M, Lhor Y, Diallo A, Lancelot R, Albina E, Libeau G. Asian lineage of peste des petits ruminants virus, Africa. Emerg Infect Dis. 2011;17:1223-31. doi:10.3201/ eid1707.101216

28. Hong TC, Mai QL, Cuong DV, Parida M, Minekawa H, Notomi T, Hasebe F, Morita K. Development and evaluation of a novel loop-mediated isothermal amplification method for rapid detection of severe acute respiratory syndrome coronavirus. J Clin Microbiol. 2004;42:1956-196. doi:10.1128/jcm. 42.5.1956-1961.2004

29. Dadas RC, Muthuchelvan D, Pandey AB, Rajak KK, Sudhakar SB, Shivchandra SB, Venkatesan G. Development of loop-mediated isothermalamplification (lamp) assay for rapid detection of peste des petits ruminants virus (PPRV) genome from clinical samples. Indian J Comp Microbiol Immunol Infect Dis. 2012;33:7-13. doi:10.1016/j.jviromet.2015.06.005.

30. Christopher Delgado RM, Steinfeld H, Ehui S, Courbois C. Livestock to 2020: The Next Food Revolution. 1999. BRIEF 61; International Food Policy Research Institute 2033 K Street, NW Washington, DC 20006-1002 USA. doi:10.5367/000000001101293427.

31. Semedo MH. Towards the eradication of peste des petits ruminants/sheep and goat plague. Empress 360, (Animal Health) FAO. 2015;45:3. http://www. fao.org/3/fa6c6714-abb4-4bb7-8164-2c4975e6b329/i4484e.pdf. 
32. Libeau G, Prehaud C, Lancelot R, Colas F, Guerre L, Bishop DH, Diallo A. Development of a competitive ELISA for detecting antibodies to the peste des petits ruminants virus using a recombinant nucleoprotein. Res Vet Sci. 1995;58:50-5. doi:10.1016/0034-5288(95)90088-8.

33. Kerur N, Jhala MK, Joshi CG. Genetic characterization of Indian peste des petits ruminants virus (PPRV) by sequencing and phylogenetic analysis of fusion protein and nucleoprotein gene segments. Res Vet Sci.2008;85:176-83. doi:10. 1016/j.rvsc.2007.07.007.

34. Ashraf W, Khan QM, Mobeen A, Kamal H, Farooq M, Jalees MM, Diallo A, Unger H. Molecular detection and genotyping characterization of PPRV in various areas of Pakistan, 2007 to 2012. Empress 360, (Animal Health), FAO. 2015;45:14-6. http://www.fao.org/3/fa6c6714-abb4-4bb7-8164-2c4975e6b329/i4484e.pdf.

Submit your next manuscript to BioMed Central and we will help you at every step:

- We accept pre-submission inquiries

- Our selector tool helps you to find the most relevant journal

- We provide round the clock customer support

- Convenient online submission

- Thorough peer review

- Inclusion in PubMed and all major indexing services

- Maximum visibility for your research

Submit your manuscript at www.biomedcentral.com/submit
Biomed Central 